\title{
Accelerated aging test and its relationship to physiological potential of soybean seeds ${ }^{1}$
}

\author{
Thaisa Cavalieri Matera ${ }^{2 *}$ (D), Lucas Caiubi Pereira², Alessandro Lucca Braccini², \\ Francisco Carlos Krzyzanowski ${ }^{3}$, Carlos Alberto Scapim², Samara Cavalli Piana ${ }^{2}$, \\ Danilo Cesar Volpato Marteli², Renata Cristiane Pereira², Gláucia Cristina Ferri ${ }^{2}$, \\ Andreia Kazumi Suzukawa ${ }^{2}$
}

\begin{abstract}
Although accelerated aging is one of the tests most used for evaluation of the physiological quality of soybean seeds, there are few studies that relate it to other physiological tests used for the crop. In this context, the objective of this study was to investigate the relationship of accelerated aging to the results of physiological performance obtained in the vigor tests most frequently used in the soybean quality control system (germination, first count, seedling vigor classification, accelerated aging, electrical conductivity, emergence speed index, final emergence in sand substrate, and field emergence). The experiment was conducted with seeds that had different vigor levels, adopting a completely randomized experimental design with four replications. Pearson simple correlation analysis (r) and simple linear regression analysis at both $1 \%$ and $5 \%$ probability were conducted on the data. The results showed that the seedling vigor classification test $(r=0.9160)$ and the field emergence test $(r=0.9198)$ were those that best correlated with accelerated aging, followed by the germination $(r=0.8690)$, first count of germination $(r=0.8460)$, and electrical conductivity $(r=0.8912)$ tests.
\end{abstract}

Index terms: Glycine max, vigor, germination, emergence, Pearson.

\section{Teste de envelhecimento acelerado e suas relações com o potencial fisiológico de sementes de soja}

\begin{abstract}
RESUMO - Apesar do teste de envelhecimento acelerado ser um dos mais empregados na avaliação da qualidade fisiológica de sementes de soja, são escassos os trabalhos que o relacionam com outros testes fisiológicos empregados na cultura. Neste contexto, o objetivo neste trabalho foi investigar as relações do envelhecimento acelerado com os resultados de desempenho fisiológico obtido nos testes de vigor mais frequentemente utilizados no sistema de controle de qualidade de sementes de soja (germinação, primeira contagem da germinação, classificação do vigor da plântula, envelhecimento acelerado, condutividade elétrica, índice de velocidade de emergência, emergência final em substrato de areia e emergência em campo). O experimento foi conduzido com sementes apresentando distintos níveis de vigor, adotando-se o delineamento experimental inteiramente casualizado, com quatro repetições. Os dados obtidos foram submetidos à análise de correlação simples de Pearson (r) e análise de regressão linear simples a $1 \%$ e $5 \%$ de probabilidade. Os resultados demonstraram que o teste de classificação do vigor da plântula $(\mathrm{r}=0,9160)$ e de emergência em campo $(r=0,9198)$ foram aqueles que se correlacionaram em maior grau com o envelhecimento acelerado, seguidos pela germinação $(r=0,8690)$, primeira contagem de germinação $(r=0,8460)$ e condutividade elétrica $(r=0,8912)$.
\end{abstract}

Termos para indexação: Glycine max, vigor, germinação, emergência, Pearson.

\section{Introduction}

Soybean is the agricultural commodity of greatest economic importance in Brazil (Bornhofen et al., 2015), and

${ }^{1}$ Submitted on 08/22/2018. Accepted for publication on 05/08/2019.

${ }^{2}$ Universidade Estadual de Maringá, Av. Colombo, 5790 - Maringá, PR, Brazil. its crop area is considerably greater than the crop areas of other agricultural crops. Given the considerable expansion of the market for differentiated and segregated grains, it is crucial for Brazil as a large producer and exporter of 
soybean to emphasize the production of soybean seeds of high physiological quality. In the 2015/2016 crop season, the mean Brazilian vigor index, determined by the tetrazolium test in soybean seeds, reached the level of $81 \%$, a value considered high and superior to that of $77.6 \%$ determined in the 2014/2015 crop season.

This information shows that Brazil produces good quality seeds, but there is a margin to increase the standard of quality since physiologically superior seeds will give rise to commercial fields that are high yielding and have a high commercial standard. This will promote greater competitiveness and gains for the entire production chain (França-Neto et al., 2016; Abdelnoor, 2016). For MarcosFilho and França-Neto (2017), the quality of a seed lot is the result of the interaction of the characteristics that determine its performance potential and, consequently, the value for sowing. For that reason, it can only be identified in a consistent manner when the set of attributes of a genetic, physical, physiological, and seed health nature is considered.

To establish policies for storage, sale, and quality control of soybean seeds, seed production companies use the results of physiological tests to compare seed lots (Martins et al., 2016). One example is the use of the germination test, whose results serve as a parameter for commercialization of seeds, and they guide sowing density in setting up the crop (Fina et al., 2016). Since it is a standardized test conducted under ideal conditions for establishing seedlings, the germination test is unquestionably an excellent tool for comparing the germination potential of different seed lots.

Nevertheless, due to its limitations, especially in regard to the ideal conditions under which it is conducted, the germination test may exhibit lower sensitivity for differentiation of the physiological quality of these lots, frequently generating results that vary from those observed in the field. For that reason, control of seed quality commonly makes simultaneous use of other tests for evaluation of physiological potential, namely, vigor tests. Among other assessments, vigor tests allow the probable performance of seeds to be estimated when placed to germinate and emerge under non-ideal conditions, providing the grower with a more realistic idea of crop performance (Marcos-Filho, 2015a).

The definition of seed vigor as formulated by the Association of Official Seed Analysts (AOSA, 1983) is "the sum of all those properties which determine the potential for rapid, uniform emergence, and development of normal seedlings under a wide range of field conditions".

There are numerous tests that assess seed vigor, including those that directly or indirectly evaluate the current metabolic state of the seed to establish a relationship with emergence and storage. Such assessments include (i) the electrical conductivity test, (ii) the tetrazolium test, and (iii) tests that evaluate seedling growth. There are likewise tests that are performed with the purpose of identifying seed tolerance to stress(es), such as the cold test, the accelerated aging test, and the controlled deterioration test (Marcos-Filho, 2015a).

Based on seed performance potential under field conditions, the accelerated aging test has proven to be effective in selecting lots for sowing soybean based on the performance potential of the seed under field conditions and in evaluation of storage potential, and it may provide information with a high degree of consistency (Popinigis, 1985; Tekrony, 1995). In this test, it is considered that high vigor seed lots maintain their viability when subjected to short periods of severe adverse conditions of temperature and relative humidity (Delouche and Baskin, 1973).

The aim of this study was to investigate the relationship between the results of the accelerated aging test, conducted at $41{ }^{\circ} \mathrm{C}$ for 24 hours at the time of commercialization, with the physiological performance of seeds in the main vigor tests applied to soybean seeds. The scientific hypothesis is that evaluation of physiological potential of the seeds based on their tolerance to adverse temperature and relative humidity conditions exhibits adequate correspondence to physiological tests of a different nature, such that seed lots classified as vigorous in the accelerated aging test exhibit better physiological performance in the other tests commonly used in control of soybean seed quality.

\section{Material and Methods}

In this study we used soybean [Glycine max (L.) Merrill] seeds of different vigor levels based on the classification of França-Neto et al. (1998) for the tetrazolium test (high, medium, and low). The seeds came from commercial lots of the cultivars BMX Potência RR, 6563 RSF IPRO, 6663 RSF, M 6410 IPRO and M 6210 IPRO. After classification by the tetrazolium test, the accelerated aging test was conducted on the seeds ( 24 hours at $41{ }^{\circ} \mathrm{C}$ ), and the results constituted the treatments of this experimental study, according to Table 1 . The conditions of the test, the time and temperature, were due to the seeds having been obtained from previous seasons, and the temperature of $41^{\circ} \mathrm{C}$ for 48 hours, as recommended by the literature, would have had a very drastic effect on the seeds (Costa et al., 1984). The seeds were maintained in a cool dry chamber at a temperature of $10{ }^{\circ} \mathrm{C}$ and relative humidity of $50 \%$ to minimize the deterioration process as the study proceeded.

Seed physiological quality was evaluated by the following tests: 
Table 1. Detailed list of treatments with their respective percentages of normal seedlings in the accelerated aging test $\left(24 \mathrm{~h} / 41^{\circ} \mathrm{C}\right)$.

\begin{tabular}{ccc}
\hline Treatment & Cultivar & $\begin{array}{c}\text { Accelerated aging (\%) } \\
24 \mathrm{~h} / 41^{\circ} \mathrm{C}\end{array}$ \\
\hline 1 & 6663 RSF & 97.50 \\
2 & 6563 RSF IPRO & 91.50 \\
3 & BMX Potência RR & 91.50 \\
4 & M6210 IPRO & 89.50 \\
5 & BMX Potência RR & 87.00 \\
6 & M6410 IPRO & 73.50 \\
7 & BMX Potência RR & 73.00 \\
8 & 6563 RSF IPRO & 74.00 \\
9 & M6210 IPRO & 67.00 \\
10 & M6210 IPRO & 64.00 \\
11 & M6410 IPRO & 63.00 \\
12 & 6563 RSF IPRO & 61.00 \\
13 & M6210 IPRO & 46.00 \\
14 & M6410 IPRO & 37.00 \\
15 & 6563 RSF IPRO & 20.50 \\
\hline
\end{tabular}

Germination test (GER): This was conducted with four 50 -seed subsamples for each treatment and replication. The seeds were placed to germinate in three sheets of "Germitest" paper and moistened with distilled water using the proportion of 2.5 times the weight of the dry substrate. This material was formed into rolls, which were placed to germinate in a Mangelsdorf germinator regulated to maintain a constant temperature of $25 \pm 1^{\circ} \mathrm{C}$, following the criteria established in the Rules for Seed Testing (Brasil, 2009). The percentage of normal seedlings was evaluated on the fifth day after the beginning of the test.

First count of germination ( $F C G$ ): This was carried out together with the previous procedure, using the same method, with four 50 -seed subsamples per replication and treatment. The procedures followed the method described by Nakagawa (1999), registering the percentage of normal seedlings larger than 3.75 $\mathrm{cm}$ obtained on the third day after sowing. The results were expressed in percentage of normal seedlings.

Seedling vigor classification (VC): This test was conducted according to the method of the germination test, in which four 50 -seed subsamples were used per replication and per treatment. Evaluation was made on the fifth day after sowing according to the Rules for Seed Testing (Brasil, 2009). Normal seedlings were classified as "strong" or "weak" according to Nakagawa (1999). The results were expressed in percentage of "strong" normal seedlings.
Accelerated aging test (AA): The Gerbox method was adopted for this test. The seeds were distributed in a single layer arranged on a stainless-steel screen inserted in plastic boxes (Gerbox), containing $40 \mathrm{~mL}$ of distilled water (Krzyzanowski et al., 1991). The boxes were then closed with a lid and placed in a water-jacketed chamber (model 3015 of VWR/USA), regulated to $41 \pm 1{ }^{\circ} \mathrm{C}$ for 24 hours (Costa et al., 1984). After that, the germination test was conducted on these seeds, as described above, with four 50 -seed subsamples per treatment and replication. Evaluation was made on the fifth day after sowing, counting the number of seedlings considered as normal (Brasil, 2009). The results were expressed in percentage of normal seedlings (Marcos-Filho, 1999).

Electrical conductivity (EC): This was evaluated using the weight method (Vieira and Krzyzanowski, 1999). Eight 25 -seed subsamples were used per replication and per treatment. The seeds were weighed on an analytical balance with precision of $0.001 \mathrm{~g}$ and immersed in $75 \mathrm{~mL}$ of deionized water in disposable plastic cups $(200 \mathrm{~mL}$ capacity). They were then kept in a germination chamber at $25^{\circ} \mathrm{C}$ for 24 hours. After the period of soaking the seeds, electrical conductivity of the soaking solutions was measured by the conductivity meter Digimed DM-32. The results obtained were divided by the weight of each subsample and were expressed in $\mu \mathrm{S} . \mathrm{cm}^{-1} . \mathrm{g}^{-1}$.

Emergence speed index in sand substrate (ESI): This was conducted with four 50-seed subsamples for each treatment and replication. The sand used was first washed and placed in plastic trays. The test was conducted under greenhouse conditions and moisture was maintained with moderate waterings (Nakagawa, 1999). Daily notations were made of the number of normal seedlings that emerged, i.e., above the soil surface, up to 12 days after sowing. Results were expressed in the emergence speed index, as proposed by Maguire (1962).

Final emergence in sand substrate (FES): This test was carried out through sowing in trays containing washed sand in four 50-seed subsamples for each treatment and replication. Normal seedlings that emerged were counted at 12 days after sowing. Results were expressed in percentage.

Field emergence ( $F E$ ): This test was carried out with four 100 -seed subsamples per replication and per treatment. Each 100 -seed subsample was treated and distributed in 2-meter-length furrows at a depth of five centimeters. Seedlings were counted at 15 days after sowing and results were expressed in percentage of normal seedlings, as described by Nakagawa (1994).

The experiment was set up adopting a completely randomized experimental design with four replications, except for the field emergence variable, for which a complete block design with randomized treatments was adopted, also with four 
replications. Analysis of variance was conducted on the data of the response variables upon meeting basic presuppositions.

Analysis of variance $(p<0.05$ and $p<0.01)$ was conducted on the variables that characterized seed physiological quality using the Sisvar statistical analysis system (Ferreira, 2011). Simple linear regression analysis was performed aiming to obtain the equation to estimate the physiological performance of each treatment in the different tests evaluated. Pearson simple correlation analysis (r) at $1 \%$ and $5 \%$ probability was conducted on the data of the response variables studied by the Student $t$ test on the SAS System software.

\section{Results and Discussion}

The Pearson linear correlation coefficients ( $\mathrm{r}$ ) between the accelerated aging test and the variables FCG, GER, VC, ESI, and $\mathrm{FE}$ of physiological quality that were tested were positive and significant at $1 \%$ probability (Table 2 ). Nevertheless, final emergence in sand substrate was not significant. A negative value of Pearson correlation was found between accelerated aging and electrical conductivity.

Just as observed in this study, Diniz et al. (2013), Schuab et al. (2006), and Santorum (2011) also registered negative values for Pearson correlation between the physiological quality variables and the electrical conductivity test in soybean seeds, indicating that in simple linear association with this variable, increasing values of one variable are associated with decreasing values of the other. This response can be credited to the very nature of the electrical conductivity test, whose essence is to evaluate physiological potential based on the quantity of leachates found in the soaking solution. In it, seeds with damaged or deteriorated membranes, i.e., seeds that are potentially less vigorous, show greater release of exudates to the outside of the cell, which results in electrical conductivity values higher than those observed in seeds with a whole membrane and, therefore, more vigorous (Marcos-Filho, 2015b).

In the area of seed technology and quality, interpretation of the Pearson linear correlation coefficients is of high complexity since there are no pre-defined reference values among the different tests, and examination of the data demands subjective analysis of the authors for a determined sample set. Nevertheless, there is consensus that the closer the correlation is to -1 or 1 , the stronger the degree of correlation between the variables.

In this respect, based on the study of Figueiredo Filho and Silva Junior (2009), Gonçalves et al. (2017) suggest that in physiological analyses of onion seeds, a correlation coefficient in absolute values from 0.1 to 0.39 can be considered weak, from 0.4 to 0.69 , moderate, and from 0.7 on, strong. To compare the results obtained in the present study, the scale proposed by Gonçalves et al. (2017) was used, however, considering results above 0.9 as very strong, as adopted by Santorum (2011).

The interpretation scale cited above was taken as a basis for discussion and comparison of the results of correlation of the accelerated aging test with the other tests used in this study.

Based on Table 2 and on interpretations of the degree of linear association, correlation values classified as very strong were obtained between the accelerated aging test and the seedling vigor classification variable $(r=0.9160)$ and the field emergence variable $(r=0.9198)$. For the germination $(r=0.8690)$, first count of germination $(r=0.8463)$, and electrical conductivity $(r=-0.8912)$ variables, the degree of linear association with accelerated aging was strong.

Table 2. Estimated Pearson linear correlation coefficients (r) between the response variables: accelerated aging (AA), first count of germination (FCG), germination (GER), seedling vigor classification (VC), electrical conductivity (EC), final emergence in sand substrate (FES), emergence speed index (ESI), and field emergence (FE).

\begin{tabular}{cccccccc}
\hline & FCG & GER & VC & EC & FES & ESI \\
\hline AA & $0.8463^{* * *}$ & $0.8690^{* * *}$ & $0.9160^{* * *}$ & $-0.8912^{* * *}$ & $0.3291^{* \text { ns }}$ & $0.5010^{* * *}$ & $0.9198^{* * *}$ \\
FCG & - & $0.8085^{* * *}$ & $0.7722^{* * *}$ & $-0.8220^{* * *}$ & $0.2964^{* \mathrm{~ns}}$ & $0.4787^{* * *}$ & $0.7857^{* * *}$ \\
GER & - & - & $0.8708^{* * *}$ & $-0.7812^{* * *}$ & $0.4820^{* * *}$ & $0.6627^{* * *}$ & $0.8194^{* * *}$ \\
VC & - & - & - & $-0.8757^{* * *}$ & $0.3895^{* * *}$ & $0.5322^{* * *}$ & $0.9302^{* * *}$ \\
EC & - & - & - & - & $-0.3939^{* * *}$ & $-0.4946^{* * *}$ & $-0.8437^{* * *}$ \\
FES & - & - & - & - & - & $0.6963^{* * *}$ & $0.3482^{* * *}$ \\
ESI & - & - & - & - & - & - & $0.5302^{* * *}$ \\
\hline
\end{tabular}

*: significant at $5 \%$ probability by the $t$ test;

Ns: not significant at $5 \%$ probability by the $t$ test;

**: significant at $1 \%$ probability by the $t$ test;

ns: not significant at $1 \%$ probability by the $t$ test. 
Such results corroborate Schuab et al. (2006), who evaluated the physiological quality of soybean genotypes and also indicated higher values of correlation between the accelerated aging test and the tests of percentage of field emergence, electrical conductivity, germination, and first count of germination. In the same way, for the soybean crop, Carvalho et al. (2009) and Barbieri et al. (2013) reported higher values of simple correlation between electrical conductivity and accelerated aging, while for Santorum (2011), the correlation of these values was generally of intermediate intensity.

In other crops of agricultural interest, Contreras and Barros (2005) and Bertolin et al. (2011) observed higher values of simple positive correlation between the accelerated aging test and seedling field emergence for sunflower and common bean seeds, respectively.

However, this study, in which the degree of correlation between accelerated aging and final emergence in sand substrate was weak $(\mathrm{r}=0.3291)$, contrasted with Diniz et al. (2013) and Schuab et al. (2006), who indicated intermediate values of coefficients between these variables. Furthermore, linear association between accelerated aging and the emergence speed index $(r=0.5010)$ exhibited moderate correlation intensity. A similar response was indicated by Santorum (2011).

In regard to the emergence test in sand, taking amplitude as the dispersion measure, a variation of $6.13 \%$ was obtained in this study between the treatments with greatest $(99.5 \%)$ and least (93.37\%) mean percentage of normal seedlings. In contrast, higher amplitudes were found in the accelerated aging test and in the percentage of field emergence, which exhibited values of $77 \%$ and $23.25 \%$, respectively. These values show the same tendency as found by Braccini et al. (1994), Schuab et al. (2006), MarcosFilho et al. (2009), Krzyzanowski et al. (2014), and Brzezinski et al. (2017), who found lower amplitude in the percentage of normal seedlings in untreated seed lots or in high vigor seed lots analyzed immediately after the treatment. However, for seeds treated and stored, the recent results of Brzezinski et al. (2017) confirm that, under these conditions, the test contributes to vigor ranking of the seed lots.

This response in the emergence test in sand therefore indicates its lower relative sensitivity in separating soybean seeds into different vigor levels under determined conditions, as aspect that may have contributed to the weak correlation observed in the accelerated aging test. However, for FrançaNeto and Henning (1992), the use of this test in the soybean crop, even in high vigor seeds, is justified by the fact of it preventing rejection of lots that have low germination (in paper substrate) caused by infection by seed coat fungi (Phomopsis spp. and/or Fusarium spp.) since under the conditions of the test, the seeds become less susceptible to these pathogens.
Finally, except for the final emergence test in sand substrate, which had low accuracy in distinguishing vigor, the accelerated aging test correlated in a satisfactory way with the other tests conducted. Especially prominent was its association with the vigor classification and field emergence tests, the latter being considered a fundamental parameter of establishment of the crop (stand) and, consequently, of grain yield.

Relatively high values of coefficients of determination were obtained for the linear equations obtained from the dependent variables of field emergence $\left(R^{2}=0.8385\right)$, vigor classification $\left(\mathrm{R}^{2}=0.8396\right)$, and electrical conductivity $\left(\mathrm{R}^{2}=\right.$ 0.8047 ) (Table 3 ). These results indicate that, with appropriate accuracy, a considerable part of these data can be explained by the simple linear regression model. Such results corroborate the Pearson linear correlation values found between these variables and accelerated aging (Table 2). Although this coefficient does not differentiate between independent and dependent variables (the value of the correlation between variable $\mathrm{X}$ and $\mathrm{Y}$ is the same as between $\mathrm{Y}$ and $\mathrm{X}$ ), the coefficient had indicated the existence of a strong or very strong linear association between these variables.

For the dependent variables of first count of germination and germination, the coefficients of determination obtained were 0.7125 and 0.7445 , respectively, indicating that even though accuracy was lower than the levels found above, the quality of the linear model of accelerated aging, with these response variables, can be considered satisfactory. Furthermore, the variables that exhibited moderate or weak intensities in

Table 3. Mathematical statistical model with agronomic interpretation of the response variables: first count of germination (FCG), germination (GER), seedling vigor classification (VC), electrical conductivity (EC), final emergence in sand substrate (FES), emergence speed index (ESI), and field emergence (FE), obtained by simple linear regression analysis.

\begin{tabular}{cc}
\hline \multicolumn{2}{c}{$\mathrm{y}=\alpha+\beta . \mathrm{x}$} \\
\hline Agronomic Model & $\mathrm{R}^{2}$ \\
\hline $\mathrm{FCG}=50.89+0.46071 \mathrm{AA}$ & 0.7125 \\
$\mathrm{GER}=70.24+0.28003 \mathrm{AA}$ & 0.7445 \\
$\mathrm{GER} / 1=0.93+0.46996 \mathrm{AA}$ & 0.7079 \\
$\mathrm{VC}=5.947+0.73881 \mathrm{AA}$ & 0.8396 \\
$\mathrm{EC}=161.344-0.93127 \mathrm{AA}$ & 0.8047 \\
$\mathrm{FES}=93,81087+0,04800855 \mathrm{E} . \mathrm{A}$. & 0.1015 \\
$\mathrm{ESI}=7.998+0.01372832 \mathrm{AA}$ & 0.2392 \\
$\mathrm{FE}=44.887+0.395204 \mathrm{AA}$ & 0.8385 \\
\hline
\end{tabular}

${ }^{\prime \prime}$ : transformation in $\arcsin \sqrt{x / 100}$.

Alpha: $1 \%$ probability. 
Pearson correlation with accelerated aging also obtained very low coefficients of determination in regression analysis. This is the case of the emergence speed index $\left(\mathrm{R}^{2}=0.2392\right)$ and of final emergence in sand substrate $\left(\mathrm{R}^{2}=0.1015\right)$, indicating that the linear mathematical model does not adequately explain the variability of the data of these response variables with reliability.

Similar to what was found in this study, Torres et al. (2004) signaled that, based on regression analysis, the accelerated aging test allowed adequate estimation of field emergence of soybean seeds, even though, according to the authors, the quality of adjustment of the model $\left(\mathrm{R}^{2}\right)$ diminished when the seeds were placed to emerge in the field outside the time window for sowing recommended in the climate zone (unfavorable climate conditions). Moreover, these authors observed that $\mathrm{R}^{2}$ and, consequently, the accuracy of the model in estimating field emergence increased when only highly vigorous seeds were subjected to regression analysis. Santorum (2011) also registered high $\mathrm{R}^{2}$ between field emergence and accelerated aging in the simple linear regression test.

Considering only the response variables that showed strong or very strong linear correlation and, consequently, $\mathrm{R}^{2}>0.70$ in simple linear regression analysis, for each unit of percentage increase in accelerated aging, the vigor classification increases the normal seedlings classified as strong by $0.73881 \%$ and the percentage of field emergence of normal seedlings by $0.39520 \%$, whereas electrical conductivity decreases by $0.93127605 \mu \mathrm{S} . \mathrm{cm}^{-1} . \mathrm{g}^{-1}$, according to the equations shown in Table 3.

Preliminary data obtained by França-Neto et al. (2002) indicate that when performed at the time of sowing, the accelerated aging test $\left(41^{\circ} \mathrm{C}, 100 \% \mathrm{RH}\right.$, for $\left.24 \mathrm{~h}\right)$ was an adequate parameter for estimating field emergence of the soybean crop. Such results were observed in numerous experiments from 1998 to 2002, in which simple linear regression analysis was conducted on the values of physiological quality obtained from various cultivars. The equation obtained in the period from 1998-2002 $(\mathrm{FE}=29.506+0.6258 \mathrm{AA})$, which, according to the authors, was similar to the equations obtained for each year separately, showed that the accelerated aging test was effective in predicting soybean seed emergence in the field.

Finally, once applied to a wide data set of physiological quality, the equations obtained will constitute an auxiliary tool in interpretation of the vigor level of soybean seed lots, based on the accelerated aging test.

\section{Conclusions}

The seedling vigor classification test and field emergence are strong, linear, and positively correlated to the accelerated aging test. To a lower degree, though still high, germination, first count of germination, and electrical conductivity also correlated to the accelerated aging test.

The analyses of simple linear regression indicate that, with high accuracy, the accelerated aging test can be used to predict seed performance in the field emergence, seedling vigor classification, and electrical conductivity tests. Thus, with the wide data set of physiological quality, the equations obtained will constitute an auxiliary tool in interpretation of the vigor level of soybean seed lots, based on the accelerated aging test.

\section{References}

ABDELNOOR, R.V. Conjuntura econômica da soja e metodologia de avaliação de qualidade. Qualidade de sementes e grãos comerciais de soja no Brasil - safra 2015/2016. Londrina: Embrapa Soja, 2016. 227p.

AOSA. ASSOCIATION OF OFFICIAL SEED ANALYSTS. Seed vigor testing handbook. Contribution to the Handbook on Seed Testing, 1983. p.32.

BARBIERI, A.P.P.; MATTIONI, N.M.; HAESBAERT, F.M.; ANDRADE, F.F.; CABRERA, I.C.; MERTZ, L.M. Teste de condutividade elétrica individual em sementes de soja e a relação com emergência de plântulas a campo. Interciência, v.38, n.4, p.310316, 2013. http://www.redalyc.org/pdf/339/33926985001.pdf

BERTOLIN, D.C.; DE SÁ, M.E.; MOREIRA, E.R. Parâmetros do teste de envelhecimento acelerado para determinação do vigor de sementes de feijão. Revista Brasileira de Sementes, v.33, n.1, p.104112, 2011. http://www.scielo.br/pdf/rbs/v33n1/12.pdf

BORNHOFEN, E.; BENIN, G.; GALVAN, D.; FLORES, M.F. Épocas de semeadura e desempenho qualitativo de sementes de soja. Pesquisa Agropecuária Tropical, v.45, n.1, p.46-55, 2015. https:// www.revistas.ufg.br/pat/article/view/29143

BRACCINI, A.L.; REIS, M.S.; SEDIYAMA, C.S.; SEDIYAMA, T. Avaliação da qualidade fisiológica e sanitária da semente de genótipos de soja (Glycine max (L.) Merrill) com diferentes graus de impermeabilidade do tegumento. Revista Brasileira de Sementes, v.6, n.2, p.195-200, 1994.

BRASIL. Ministério da Agricultura Pecuária e Abastecimento. Regras para análise de sementes. Ministério da Agricultura Pecuária e Abastecimento. Secretaria de Defesa Agropecuária. Brasília, DF: MAPA/ACS, 2009. 395p. http://www.agricultura.gov.br/assuntos/ insumos-agropecuarios/arquivos-publicacoes-insumos/2946_ regras_analise_sementes.pdf

BRZEZINSKI, C.R.; ABATI, J.; HENNING, F.A.; HENNING, A.A.; FRANÇA-NETO, J.B.; KRZYZANOWSKI, F.C.; ZUCARELI, C. Spray volumes in the industrial treatment on the physiological quality of soybean seeds with different levels of vigor. Journal of Seed Science, v.39, n.2, p.174-181, 2017. http:/www.scielo.br/pdf/jss/ v39n2/2317-1545-jss-39-02-00174.pdf

CARVALHO, L.F.; SEDIYAMA, C.S.; DIAS, D.C.F.S.; REIS, M.S.; MOREIRA, M.A. Teste rápido de condutividade elétrica e correlação com outros testes de vigor. Revista Brasileira de Sementes, v.31, n.1, p.239-248, 2009. http://www.scielo.br/pdf/rbs/v31n1/a27v31n1.pdf 
CONTRERAS, S.; BARROS, M. Pruebas de vigor em semillas de Lechuga y su correlación com emergencia. Ciência y Investigacion Agrária, v.32, n.1, p.3-11, 2005. https://rcia.uc.cl/index.php/rcia/ article/view/301

COSTA, N.P.; PEREIRA, L.A.G.; FRANÇA-NETO, J.B.; HENNING, A.A.; KRZYZANOWSKI, F.C.; BARRETO, J.N.; PRADERI, E.V. Padronização do teste de envelhecimento precoce. In: Embrapa. Centro Nacional de Pesquisa de Soja. Resultados de pesquisa de soja 1983/1984. Londrina, 1984. p.119-120.

DELOUCHE, J.C.; BASKIN, C.C. Accelerated aging techniques for predicting the relative storability of seed lots. Seed Science and Technology, v.1, p.427-452, 1973. http://ir.library.msstate.edu/ bitstream/handle/11668/13316/F-4.pdf?sequence $=1$

DINIZ, F.O.; REIS, M.S.; DIAS, L.A.S.; ARAÚJO, E.F.; SEDIYAMA, T.; SEDIYAMA, C.A. Physiological quality of soybean seeds of cultivars submitted to harvesting delay and its association with seedling emergence in the field. Journal of Seed Science, v.35, n.2, p.147-152, 2013. http://www.scielo.br/pdf/jss/v35n2/02.pdf

FERREIRA, D.F. Sisvar: a computer statistical analysis system. Ciência e Agrotecnologia, v.35, n.6, p.1039-1042, 2011. http://www. scielo.br/pdf/cagro/v35n6/a01v35n6.pdf

FIGUEIREDO FILHO, D.B.; SILVA JUNIOR, J.A. Desvendando os mistérios do coeficiente de correlação de Pearson (r). Revista Política Hoje, v.18, n.1, p.115-146, 2009. https://www.researchgate.net/ profile/Dalson_Figueiredo2/publication/290157754_Desvendando_ os_Misterios_do_Coeficiente_de_Correlacao_de_Pearson_r $\mathbf{r} /$ links $/ 5944226 \bar{b}$ aca $2722 \mathrm{db} 49 \mathrm{~d} 10 \overline{79} / \overline{\text { Desvendando-os-Misterios-do- }}$ Coeficiente-de-Correlacao-de-Pearson-r.pdf

FINA, B.L.; LUPO, M.; DRI, N.; LOMBARTE, M.; RIGALLI, A. Comparison of fluoride effects on germination and growth of Zea mays, Glycine max and Sorghum vulgare. Journal of the Science of Food and Agriculture, v.96, n.11, p.3679-3687, 2016. https:// onlinelibrary.wiley.com/doi/full/10.1002/jsfa.7551

FRANÇA-NETO, J.B.; HENNING, A.A. Diagnóstico completo da qualidade da semente de soja [DIACOM]. Londrina: Embrapa/ CNPSo, 1992. 22p.

FRANÇA-NETO, J.B.; KRZYZANOWSKI, F.C.; COSTA, N.P. $O$ teste de tetrazólio em sementes de soja. Londrina: Embrapa/CNPSo, 1998.72p.

FRANÇA-NETO, J.B.; KRZYZANOWSKI, F.C.; COSTA, N.P.; HENNING, A.A.; PÁDUA, G.P. Adequação da metodologia de testes de vigor para sementes de soja. Resultados de pesquisa da Embrapa Soja-2002: sementes e transferência de tecnologia. Embrapa Soja, 2002. p.25-32. file:///C:/Users/Usu\%C3\%A1rio/ Downloads/Resultados-de-pesquisa-da-Embrapa-Soja-2002sementes-e-transferencia-de-tecnologia\%20(1).pdf

FRANÇA-NETO, J.B.; KRZYZANOWSKI, F.C.; HENNING, A.A.; PÁDUA, G.P.; LORINI, I.; HENNING, F.A. Tecnologia da produção de semente de soja de alta qualidade. Londrina: Embrapa Soja, 2016. 82p. https://ainfo.cnptia.embrapa.br/digital/bitstream/ item/151223/1/Documentos-380-OL1.pdf
GONÇALVES, N.R.; CICERO, S.M.; ABUD, H.F. Seedling image analysis and traditional tests to evaluate onion seed vigor. Journal of Seed Science, v.39, n.3, p.216-223, 2017. http://www.scielo.br/pdf/ jss/v39n3/2317-1545-jss-39-03-00216.pdf

KRZYZANOWSKI, F.C.; FRANÇA-NETO, J.B.; HENNING, A.A. Relato dos testes de vigor disponíveis para as grandes culturas. Informativo ABRATES, v.1, n.2, p.15-53, 1991.

KRYZANOWSKI, F.C.; HENNING, A.A.; HENNING, F.A.; FRANÇA-NETO, J.B.; LORINI, I. Influência do volume de calda e da combinação de produtos usados no tratamento da semente de soja sobre o seu desempenho fisiológico. Resumos expandidos da XXXIV Reunião de Pesquisa de Soja, 2014.

MAGUIRE, J.D. Speed of germination aid in selection and evaluation for seedling emergence and vigor. Crop Science, v.2, n.2, p.176-77, 1962. https://dl.sciencesocieties.org/publications/cs/ abstracts/2/2/CS0020020176

MARCOS-FILHO, J. Fisiologia de sementes de plantas cultivadas. 2.ed. Londrina: ABRATES, 2015b. 659p.

MARCOS-FILHO, J. Seed vigor testing: an overview of the past, present and future perspective. Scientia Agricola, v.72, n.4, p.363-374, 2015a. http://www.scielo.br/pdf/sa/v72n4/0103-9016-sa-72-4-0363.pdf

MARCOS-FILHO, J. Teste de envelhecimento acelerado. In: KRZYZANOWSKI, F.C.; VIEIRA, R.D.; FRANÇA-NETO, J.B. (eds.). Vigor de sementes: conceitos e testes. Londrina: ABRATES, 1999. p.1-24.

MARCOS-FILHO, J.; FRANÇA-NETO, J.B. Vigor de sementes: um componente de qualidade em permanente evolução. Seed News, v.21, n.5, p.42-49, 2017. https://seednews.com.br/edicoes/28-onegocio-de-sementes-nos-eua-xxi-\%7C-01-janeiro-2017

MARCOS-FILHO, J.; KIKUTI, A.L.P.; LIMA, L.B. Métodos para avaliação do vigor de sementes de soja, incluindo a análise computadorizada de imagens. Revista Brasileira de Sementes, v.31, n.1, p.102-112, 2009. http://www.scielo.br/scielo. php?script $=$ sci_arttext\&pid $=$ S0101-31222009000100012\&lng $=$ pt \&tlng=pt

MARTINS, C.C.; UNÊDA-TREVISOLI, S.H.; MÔRO, G.V.; VIERA, R.D. Metodologia para seleção de linhagens de soja visando germinação, vigor e emergência em campo. Revista Ciência Agronômica, v.47, n.3, p.455-461, 2016. http://www.ccarevista.ufc. $\mathrm{br} /$ seer/index.php/ccarevista/article/view/4151

NAKAGAWA, J. Testes de vigor baseados na avaliação das plântulas. In: VIEIRA, R.D., CARVALHO, N.M. (ed.). Testes de vigor em sementes. Jaboticabal: FUNEP, 1994. p.49-85.

NAKAGAWA, J. Testes de vigor baseados no desempenho das plântulas. In: KRZYZANOWSKI, F.C.; VIEIRA, R.D.; FRANÇANETO, J.B. (eds.). Vigor de sementes: conceitos e testes. Londrina: ABRATES, 1999. p.1-21.

POPINIGIS, F. Fisiologia da semente. Brasília: AGIPLAN, 1985. 289p.

SANTORUM, M. Comparison of tests for analysis of soybean seed vigor and its relationship to field emergence. 113 f. Dissertação (Mestrado em Engenharia) - Universidade Estadual do Oeste do Paraná, Cascavel, 2011. 
SCHUAB, S.R.P.; BRACCINI, A.L.; FRANÇA-NETO, J.B.; SCAPIM, C.A.; MESCHEDE, D.K. Potencial fisiológico de sementes de soja e sua relação com a emergência das plântulas em campo. Acta Scientiarum. Agronomy, v.28, n.4, p.553-561, 2006. http://www.redalyc.org/html/3030/303026571017/

TEKRONY, D.M. Accelerated ageing test. In: VAN DE VENTER, H.A (ed.). Seed Vigour Testing Seminar. Copenhagen: ISTA, 1995. p.53-72.
TORRES, R.M.; VIEIRA, R.D.; PANOBIANCO, M. Accelerated aging and seedling field emergence in soybean. Scientia Agricola, v.61, n.5, p.476-480, 2004. http://www.scielo.br/pdf/sa/v61n5/21444.pdf

VIEIRA, R.D.; KRZYZANOWSKI, F.C. Teste de condutividade elétrica. In: KRZYZANOWSKI, F.C.; VIEIRA, R.D.; FRANÇANETO, J.B. (eds.). Vigor de sementes: conceitos e testes. Londrina: ABRATES, 1999. p.1-26. 